\title{
GENDER JUSTICE PARADOX: WOMEN IN MANAGEMENT POSITIONS IN SCIENCE AND TECHNOLOGICAL INSTITUTIONS IN THE CENTRAL ZONE OF MEXICO
}

\section{E. Sanchez-Cruz*}

Department of Foreign Students

e-mail: esanche@alumni.uwo.ca

\author{
A. Masinire \\ Curriculum Studies Division \\ University of the Witwatersrand \\ Johannesburg, South Africa \\ e-mail: Alfred.Masinire@wits.ac.za / https://orcid.org/0000-0002-1329-8569

\section{Gerónimo-Vázquez*} \\ Masters Student, International Studies Department \\ e-mail: chintita12@hotmail.com \\ ${ }^{*}$ Colegio de Veracruz \\ Xalapa, Mexico
}

\section{ABSTRACT}

The past fifty years have witnessed intense local and international gender equity activism. However, the gender landscape has not transformed significantly to reflect a gender equal and just space. Men continue to occupy top influential political and economic positions. While current theoretical work on gender has developed incisive analytic tools which problematise gender essentialism, normative gender stereotypes persist and continue to dominate the institutional practices in many management positions in technological institutions in Mexico. The purpose of this study was to interrogate gender representation in key management positions in the state technological institutes of the central zone of Mexico. We analysed employment and recruitment documents available on the national database and compared the statistics on gender lines to establish the percentage of male and female managers in the science and technological institutes. The results showed that a greater proportion of management positions were occupied by men who were underqualified academically and professionally. Though there were few women in these posts, those women had appropriate and relevant qualifications. We conclude that gender difference may be used to explain the gender biased employment practices in key leadership positions in the technological institutes in Mexico. We also suggest possible research, policy and practical implications beyond the borders of Mexico.

Keywords: gender equity, public management in education, higher education, science and technology, Mexico 


\section{INTRODUCTION}

In recent decades, Mexico as a nation has adopted and implemented policies in favour of gender equity, the empowerment of women and their access to a life without violence. However, despite its policy advances, Mexico still has a long way to go before it reaches substantive gender equality. According to a report by the Organisation for Economic Cooperation and Development (OECD) (2017b), Mexico has one of the highest disparities in terms of employment by gender in the world, and that ultimately and negatively impacts economic growth. Therefore, it can be said that although it is necessary to implement policies and initiatives with a gender perspective, the impact has not translated significantly into material and social benefits in women's lives. The current gender structure organised on patriarchal lines benefits men as a social category and disadvantages women as a group (Connell 1995). Gender inequality and discrimination persists and has a global dimension (Connell 2005). Men, as opposed to women, continue to occupy influential and leadership positions in most structures of society such as economic, political, military, and cultural institutions.

Feminist literature seems to suggest that the fight against gender inequality has progressed through three logical and distinct phases; viz the first, second and third feminist waves (Lorber 2010). The first wave emerged in the late $19^{\text {th }}$ up to the early $20^{\text {th }}$ century and fought for the basic human rights of women which we may take for granted today. These rights included the right to vote, to own property, to borrow money, to work and earn an income, to study, to initiate a divorce and to represent themselves in court (Lorber 2010,2). Today it appears unthinkable that women did not have these rights. We would expect that after more than a century and half years of intense gender equality advocacy, policy pronouncements and programmatic interventions, communities would have changed to reflect a gender equal and just world. The paradox is that in some parts of the world, especially in the global south, women still bear the unequal gender burden confronted by women in the global north during the first feminist wave. In higher education there are academic programmes which are dominated by men. The science and technology disciplinary areas are a good example. The top positions still reflect a gender imbalance in favour of men. This suggests that men are still guarding high profile management positions in the previously considered male-dominated professions.

Among all the challenges and opportunities that exist today in the world, it can be seen that countries that promote and support gender equality enjoy higher levels of economic growth and performance and political and social stability. It can be argued that many countries in the world are signatories to the United Nations Declaration of Human Rights, a convention which upholds the equality of human beings regardless of their social class, gender, race and religion. 
As a result, among other rights, it becomes obligatory for the signatory countries to move from policy commitment to practical action and to adopt decisive public policies and measures aimed at achieving women's access to administrative and leadership positions, and access and participation in higher education.

A gendered society is prone to repeat inequality in all the institutions that constitute it because it is based on stereotypes and social prejudices. The unequal structures of such a society are upheld, promoted and maintained as culturally and naturally acceptable without question. In the words of Lamas $(1996,216)$ "It is not enough to declare equal treatment, when in reality, there is no equality of opportunity". In this article we examine the gender policy contexts of social institutions such as technological institutes in Mexico in order to understand the extent to which they enact gender sensitive and responsive practices. Specifically, we focus on understanding the representation of women in management positions in higher education technology institutes.

In this article, we argue that the public administration of higher education, particularly administration of higher education technology institutes, along with the policies that promote the gender perspective, is a priority area that should be researched, assessed and strengthened in order to benefit those who have been previously disenfranchised through systematic gender discrimination. This article provides an audit of the gains made in advancing the social and gender positions of female employees in technological institutions in Mexico. Science and technology institutions are notoriously renowned for their male gender bias where male participation is depicted as a measure of celebrated and normative masculinity (Volman, Van Eck and Ten Dam 1995). In relation to the public administration, there is need to closely understand which gender dominates in the management positions in higher education of the technological institutions of the Central Zone of Mexico.

Many studies on participation in science and technology have focused predominantly on girls' uptake of science, technology, engineering and maths subjects (STEM) at high school level (Blickenstaff 2005) and higher education (Kelley and Bryan 2018). However, the entry of women into the management structures of these institutions at tertiary level has remained unexplored. Ducklin and Ozga (2007) have provided an entry point into this limited research as they explore women in senior management positions in further education. Though significant by focusing on women in senior management in further education, their study has no special focus on science and technology which is usually male dominated (Lynch and Nowosenetz 2009). By focusing on women in management positions in institutes of technology we can obtain a better understanding of gender in this previously male-dominated field and thereby help to recognise and address the challenges, stereotypes and systematic inequalities that 
persistently continue to plague the public administration of higher education in Mexico. The study is particularly significant given that a raft of gender equity policies have been implemented recently. The article thus aims to address the question of what gains have been made to date in terms of women's advancement in senior management positions in higher education technological institutions in Mexico.

In developing our argument the first section, above, has provided the background and outline of statement of purpose. In the second section we will describe the global policy context of gender. The third section will briefly discuss the status of women in public spaces with a special focus on higher education institutions. In the fourth section we will outline the context of the study, that is, the technological institutes of the Central Zone of Mexico. In the final section we will present the data, discuss the findings and policy and research implications.

\section{THE GLOBAL AND NATIONAL POLICY CONTEXT OF GENDER}

Constitutionally women in Mexico enjoy the same full legal rights as men. Following these legal statutes is an apparent gender institutionalisation in public institutions and an increase in public resources earmarked exclusively for gender equality. The national gender policy initiatives should be understood in the context of global agendas to address gender inequality. Mexico is a signatory to international human rights treaties envisaged to end poverty, illiteracy, gender violence and human slavery and trafficking. Among the current international treaties which aim to prevent, punish and eradicate violence against women are the Charter of the United Nations, the Convention on the Political Rights of Women, the International Covenant on Civil and Political Rights, the Convention on the Elimination of All Forms of Discrimination Against Women (CEDAW), the Charter of the Organization of American States, and the InterAmerican Convention on the Granting of Political Rights to Women.

These international agreements were borne out of the human catastrophes of World War 1 and World War 2. The agreements are designed to promote peace, development and healthy coexistence among the members of society. In addition, they are aimed at addressing the plight of half of the population, that is, women, with the aim of eliminating discrimination and achieving a more equitable and democratic development between men and women. In this context, it has become urgent to review the cultural, economic and socio-political contexts that surround and engender discrimination against women in a country such as Mexico where legal and administrative policy frameworks support a gender perspective.

By signing and ratifying international treaties, Mexico has assumed responsibilities regarding basic rights and freedom for women in all areas of life, including those related to the political rights of women and their inclusion in public administration. In addition to 
international treaties, there is a constitutional guarantee in Article 4 that promotes equality between men and women; thus, it can be argued that there is deliberate and affirmative action to achieve gender parity.

Based on the international treaties and locally designed constitutional declaration of human rights, Mexico has committed itself to promote and guarantee gender equality and the empowerment of women (UN-Women 2015). In terms of public administration actions, gender quotas aim to increase female political participation, which is a step to increasing their representation in decision-making. The initiative regularly imposes minimum percentages of candidates for both genders and guarantees the effective integration of women into elective decision-making positions both in political structures and in the other state organs.

Gender quotas, like many other affirmative measures, are the beginning for new policies aimed at counteracting the social constraints that discriminate against women or other groups who have lived in perpetual discrimination and vulnerability (UN-Women 2015). In addition, the Plan Nacional de Desarrollo (2013-2018) (National Development Plan) promoted for the first time an initiative for all state secretaries and government agencies to work in favour of services, opportunities and non-discrimination against women. The NDP promulgated special actions to guarantee the rights of women and avoid causes of inequality, exclusion or discrimination (Plan Nacional de Desarrollo 2013-2018).

Another initiative to achieve gender equality in public institutions is an increase of public resources earmarked for equality. This initiative allocates financial resources destined for the generation, monitoring and evaluation of programmes; analysis and development of legislation; as well as the generation of public policies with a view to accelerating equality between men and women (Economic Commission for Latin America and the Caribbean 2013). The above international and national gender policy context sets a gender-friendly environment susceptible to a just and equal community. However, the extent to which these policies have translated into material benefits for women is not clear. More specifically, this article study to assess whether women have managed to enjoy leadership and management positions in technology institutes in Mexico.

\section{EDUCATION AND GENDER IN MEXICO}

Mexico has made significant strides in achieving universal access to primary education. However, important gender equity challenges persist hampering the advancement towards numerical equality in higher levels of education, employment and key positions. For example, in a 2010 national youth survey it was found that for women to complete their higher education studies and improve their economic condition, the main barriers were that they were engaged 
in domestic work, were pregnant and married at an early age (INEGI 2017).

Women continue to have less continuity in their studies and careers than men and have less access to the next level of education. This is reflected in the 35 per cent of women between 15 and 29 years old who do not study, train or work (the so-called ninis) (OECD 2017a). However, the biggest challenge in this area is the persistent gender segregation in the job market. Although the participation of women has increased in recent years, they remain a minority in the fields of science, mathematics, engineering and technology (UNDP 2017).

To encourage the participation of women in all areas of knowledge, but mainly in those related to science and research, the gender perspective strategy has been proposed within the National Development Plan (2013-2018). The initiative considers the Index of Gender Inequality as part of its evaluation indicators. In relation to the access of women as a workforce in the academy, there has been e a decline in the number of female academic staff being promoted to higher decision making positions in the universities (Ordorika 2015). This is happening despite the transformational commitment number 3 on equal opportunities and nondiscrimination against women in the Programa Sectorial de Educación (Sectorial Education Program) 2013-2018. Strategy 2 suggests "Promoting the perspective of gender and human rights in planning processes and evaluation of the education sector "(Programa Sectorial de Educación 2013).

\section{HIGHER EDUCATION TECHNOLOGY INSTITUTES (ITES)}

Mexico already had ITES, it was not until 2014 that the Presidential Decree was published to create a decentralised regulatory body of the Ministry of Public Education with the objective of coordinating the subsystem of technologically superior education under the name of Tecnológico Nacional de México (Diario Oficial de la Federación 2014).

The National Technological Institute of Mexico consists of 266 institutions of higher education distributed in the 32 states of the Republic (Subsecretaria de Educación Superior 2018). The ITES are divided into 126 federal and 134 decentralized institutes, four Regional Centers of Optimization and Development of Equipment (CRODE), an Interdisciplinary Center for Research and Teaching in Technical Education (CIIDET) and a National Center for Technological Research and Development (CENIDET). The student population divided between undergraduate and postgraduate students is approximately 521105 students (TECNM 2018b) and it offers 35 engineering degrees, degrees in Architecture, Public Accountant, Gastronomy, and Bachelor's degrees (Administration, Biology and Tourism).

ITES have a solid tradition that dates back more than 65 years, in which its technological production of excellence in the country stands out (Subsecretaria de Educación Superior 2018). 
Part of their vision is "To be one of the fundamental pillars of sustained, sustainable and equitable development of the nation" (Vega et al. 2012, 27) and part of its mission is, "To offer education services, superior technological quality, with national coverage, pertinent and equitable, that contributes to the confirmation of a fair and humane society, with a perspective of sustainability" (Vega et al. 2012, 27).

Based on the mission and vision of the ITES, there is a clear interest in fostering equitable development to create a just and humane society, which undoubtedly includes its academic, administrative and student population. In turn, the ITES commit to:

"Promote equal opportunities in the access and promotion of employment, prevention of sexual harassment and non-discrimination between men and women; through the development of affirmative actions and / or in favor of the staff, with the purpose of maintaining a harmonious working environment and favoring gender equality" (TECNM 2018c, 1).

Thus, in addition to promoting a fair, inclusive and equitable society, specific focus is given in the gender equity policy that emphasises equality in opportunities and non-discrimination between men and women in the promotion criteria. In addition, the ITES establish bases for the formation and development of professional competences that entail a structure and functioning of thought, fluency in formal knowledge, and a set of useful and practical resources (Vega et al. 2012). Therefore, the ITES are structured with a focus on training and development of professional skills to build high-level human capital and strong academic support.

\section{PROFESSIONAL CERTIFICATE CARD IN MEXICO}

People who study a profession are required to demonstrate certain levels of professional ethics because they work directly (or indirectly) with other human beings. Humanities careers, for example, deal directly with humans, and engineers construct objects for human use (Programa para la cohesión social en América Latina 2017). The role of the professional has become essential for the functioning of Mexican society in order defend the nation, educate children, diagnose and cure diseases, judge and punish those who violate laws, manage industry and business; as well as building buildings, repairing teeth and analysing the world of physics.

Under the logic of professionalism, in Mexico completing a bachelor degree is a different process from graduation. In this sense, each higher education institute stipulates requirements and processes for obtaining the verifiable academic certification at the national level with a professional certificate. The professional certificate serves to be able to legally exercise the profession studied in the country and is of the utmost importance for Mexican society (Gaceta Parlamentaria 2015). 
The issuance of the professional certificate is a requirement to practice as a professional in the Mexican society. As such, who obtains this certificate is of the public interest. Thus, the law itself requires a doctor, dentist, lawyer, engineer and professor among others, to exhibit the document in order to practice the profession (Gaceta Parlamentaria 2015) under the understanding that they present themselves as professionals and that society can rely on their job. Due to the social demand and the duty of the state for the transparency of the information, every professional certificate is public through a system of consultation for any citizen on line called the National Registry of Professionals portal. We would expect that the administrative management of the public offices of the Technological Institutes have also undergone a professional certification process that would make them legally certified to practices as public managers.

\section{METHODOLOGY}

The study approach was based on a review of documents as a data collection method (Sampieri, Collado and Lucio 2014). The objective was to systematically examine the National Registry of Professionals portal to identify the gender and training of ITES directors in the Central Zone of Mexico. Subsequently, the public page of professional certificates was reviewed to verify gender, career and academic degree of every director of the ITES. A table was made to distinguish gender, academic degree and area of specialisation.

Due to the size of the country, the Central Zone of the Mexican Republic was purposefully selected as the study context. There is a high concentration of ITES in the central zone of Mexico as compared to other parts of the country. According to the Programa Regional de Desarrollo del Centro (Regional Development Program of the Center) (2014), the states that comprise this geographical area are 13 states in the Central Zone of Mexico. Table 1 shows the distribution of ITES in each state.

Table 1: Number of ITES in each state in the central zone of Mexico

\begin{tabular}{|l|c|}
\hline Name of State & Number of ITES \\
\hline Aguascalientes & 0 \\
\hline Colima & 0 \\
\hline Guanajuato & 4 \\
\hline Hidalgo & 3 \\
\hline Jalisco & 13 \\
\hline Mexico City & 14 \\
\hline Michoacan & 14 \\
\hline Morelos & 11 \\
\hline Nayarit & 0 \\
\hline
\end{tabular}




\begin{tabular}{|l|c|}
\hline Name of State & Number of ITES \\
\hline Queretaro & 0 \\
\hline San Luis Potosi & 4 \\
\hline Tlaxcala & 1 \\
\hline Zacatecas & 7 \\
\hline Total & $\mathbf{7 1}$ \\
\hline
\end{tabular}

On the page of Tecnológico Nacional de México (TECNM 2018b) the ITES of the country and consequently of the Central Zone of Mexico are described. The pages were reviewed and the data were corroborated with the page of the Telephone Directory of the decentralised technicians (TECNM 2018a) on the page the full names of the Director or General Director are described.

\section{FINDINGS AND DISCUSSION OF RESULTS}

In the central area there is a total of 71 ITES with 43 male directors and 14 female directors, which reflects a 75 per cent men and 25 per cent women percentage ratio (Figure 1). That is to say, women have a much lower representation than men in the ITES as directors.

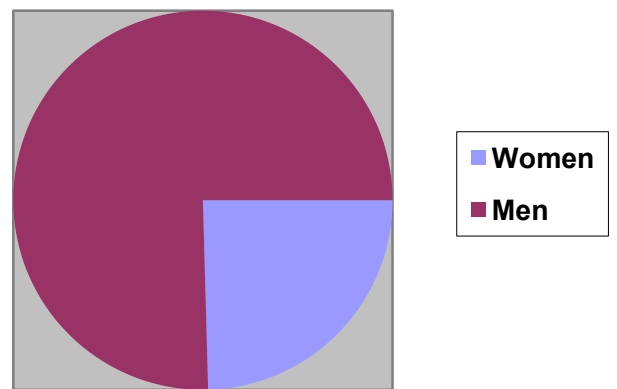

Figure 1: Distribution by gender of the directors of the ITES (Source: Own preparation with data from ITES and National Register of Professions.)

The results also indicate that women with managerial positions have a higher academic level than men considering that 43 per cent of women have a bachelor's degree, 50 per cent have a master's degree and 7 per cent have a doctoral degree (See Table 2). In other words, the academic level goes from a minimum of a bachelor's degree to a maximum of a doctorate level of education. On the other hand, most men (56\%) have a bachelor's degree, 35 per cent a master's degree, and 9 per cent do not have a professional certificate (Table 2); that is, the level goes from zero (without a certificate) to the level of Master's degree. The results show that women are better qualified academically than men, as also described in other studies (UNESCO 
2018; CNDH 2018; Angulo and Galván 2018; OECD 2017b; Subirats 1998).

The results also indicate that men can perform in high positions of public administration of the ITES with or without a professional certificate, which is not the case for women. Results from other countries are also consistent with this finding. For example, Connell (2000) notes that higher educational scores for girls/females have not translated into post-school social and economic gains. Similar traits have also been established in Africa, where men who have basic formal schooling occupy higher public and private positions than women who have advanced in formal schooling (Morojele 2011).

Table 2: Academic qualifications of Directors of ITES

\begin{tabular}{|l|c|c|c|c|}
\hline & Men & \% & Women & $\%$ \\
\hline Bachelor's & 24 & 56 & 6 & 43 \\
\hline Master's & 15 & 35 & 7 & 50 \\
\hline PhD & 0 & 0 & 1 & 7 \\
\hline No Accreditation & 4 & 9 & 0 & 0 \\
\hline Total & $\mathbf{4 3}$ & $\mathbf{1 0 0}$ & $\mathbf{1 4}$ & $\mathbf{1 0 0}$ \\
\hline
\end{tabular}

Source: Own elaboration with data from ITES and the National Registry of Professions

As regards the academic specialisation, most of the directors, both men and women, have a background in the humanities area with 37 per cent and 43 per cent respectively, followed by the exactas area with 30 per cent for men and almost 29 per cent for women (Table 3 ). Regarding the administrative economic area, almost 29 per cent of the women have training, compared to 14 per cent of men.

Table 3. Professional qualification and certification of Directors of ITES

\begin{tabular}{|l|c|c|c|c|}
\hline \multicolumn{1}{|c|}{ Area } & Men & \% & Women & \% \\
\hline Humanities & 16 & 37 & 6 & 43.0 \\
\hline Administrative-economics & 6 & 14 & 4 & 28.5 \\
\hline Engineering \& Maths & 13 & 30 & 4 & 28.5 \\
\hline Biology & 5 & 11 & 0 & 0 \\
\hline No Accreditation & 4 & 9 & 0 & 0 \\
\hline Total & $\mathbf{4 4}$ & $\mathbf{1 0 0}$ & $\mathbf{1 4}$ & $\mathbf{1 0 0}$ \\
\hline
\end{tabular}

In addition, the careers offered in the ITES belong mostly to the area of Exactas (with 35 engineering and 1 architecture), followed by the economic administrative courses (with 1 public accountant, 1 gastronomy, 1 administration, 1 tourism), and finally the area of biology (1 biology) (Table 4).

Thus, when comparing Tables 2, 3, and 4, an academic qualification is not mandatory for 
men to be appointed as directors in the ITES in the Central Zone of Mexico. The results also indicate that it is not necessary to have a background in the area of Engineering to hold a position of manager in ITES in which the specialisation is engineering.

Table 4: Careers that are offered in the ITES and training area

\begin{tabular}{|c|c|c|c|c|}
\hline Area & Faculty & Quantity & $\%$ & Total \% \\
\hline Maths and engineering & Engineering & 35 & 85.0 & \multirow[b]{2}{*}{87.5} \\
\hline Maths and engineering & Architecture & 1 & 2.5 & \\
\hline Administrative-economics & Accounting & 1 & 2.5 & \multirow[b]{4}{*}{10.0} \\
\hline Administrative-economics & Gastronomy & 1 & 2.5 & \\
\hline Administrative-economics & Administration & 1 & 2.5 & \\
\hline Administrative-economics & Tourism & 1 & 2.5 & \\
\hline \multirow[t]{2}{*}{ Biology } & Biology & 1 & 2.5 & 2.5 \\
\hline & Total & 41 & 100 & 100 \\
\hline
\end{tabular}

Considering that the academic area is not a condition for a position in the public administration of the ITES and that the ITES promotes a gender perspective in job promotions, the dominance of men over women in the ITES directorate casts doubt over the effectiveness of gender policies to bring about gender parity in the employment sector, particularly in administrative positions in ITES in Mexico.

\section{DISCUSSION OF FINDINGS AND RESEARCH IMPLICATIONS}

\section{Challenges to gender equality}

Despite the favourable gender policy framework, there are still glaring gaps in terms of implementing policies in favour of women at the national level in Mexico. Where achievement has been noted, this has not been uniform in all areas, thus marked gender inequalities persist in impacting women's potential to participate productively in all sectors of society.

According to data from the $\operatorname{UNDP}(2017,18)$, "Only $18 \%$ of women hold the position of ministers of the Supreme Court of the Nation" and only 14 per cent of the Mayorship throughout the country were held by women in the 2016 elections. The results of the UNDP then suggest a skewed female underrepresentation in key political and legislative positions of influence in the country.

In addition to the above, several indicators show that women in Mexico face a plethora of discrimination that limits their opportunities and hinders their professional advancement. For example, in the labour market, women face more unfavourable conditions than men (INEGI 2017) because a) women are concentrated in occupations with low wages or in low-skilled 
services such as domestic service (CNDH 2018); b) women are responsible for household chores which are not socially valued and financially rewarded (CNDH 2018); c) there are differences in salaries for equal work and women occupy management positions to a lesser extent than men, d) women are more concentrated in informal, lower quality jobs than men (OECD 2017b). This scenario is not peculiar to Mexico but is common in most countries throughout the world. Connell $(2005 ; 2009)$ provides a global picture of gender inequality and estimates that the gap might increase due to the neo-liberal policy context, which attempts to leave everything to individual agency and to free market forces.

There is also a high degree of occupational segregation, with marked gaps in terms of professional mobility and access to better employment opportunities in favour of men (INEGI / INMUJERES 2016). According to a study by the CNDH (2018), of 47 federal public administration institutions, 29 had a percentage higher than 40 per cent with women among the middle and upper management, which in principle indicates an attainment of the equality between women and men. However, an approximation of the percentage of women in command in contrast to the total staff shows that women have less presence in decision-making positions.

It is argued further that the situation is repeated among women with better levels of schooling at work and who do not cover decision-making positions (CNDH 2018; OECD 2017a). It should be noted that the situation also occurs even when women are better prepared academically than their male counterparts (CNDH 2018; OECD 2017b). This can be explained by the so-called glass ceiling that describes socially and culturally imposed barriers that prevent women from reaching high levels of management (González 2015).

The ITES, as well as other public institutions, promote a gender perspective in the discourse that emphasises the promotion of equal employment opportunities for men and women. This is in line with international and national gender equity policies. We examine the representation of women in positions of directors (the highest administrative position in each ITES).

The findings in this study are consistent with the above international and local literature on the persistent gender inequalities. The results show that there are fewer women than men in management positions of ITES. Thus, gender inequality in leadership positions in ITES in the central zone of Mexico is a persistent problem. It is striking that ITES promote a discourse of academic excellence while the managers themselves do not have professional qualifications which attest to their competencies to perform the job. Gender equity policy rhetoric might need significant buy-in from men otherwise it will remain an illusion for capable and aspiring female cadres. While women might have had equal access to educational opportunity or in this case seem to have surpassed men in educational attainment, these gains have not translated into 
material benefits for women. The unjust and unequal gender order continues to reward men just because they are men more than it rewards women.

This study opens up further areas of research enquiry which might help explain the breadth and depth of the persistence of gender inequality. For example, there is a need to conduct studies exploring and comparing the public administration posts of academic and sub-directorate, expand the scope of study to include the whole country of Mexico. As few women have penetrated the top hierarchy of a male-dominated occupational structure, research also needs to examine the conditions, barriers, and incentives to women's advancement in these positions. We need to ask the question: What are the experiences of these top achieving women in a working culture dominated by men? What is it like to be a woman in a management position in an ITES in Mexico? Success narratives of women in these positions might also encourage other women to aspire to these top posts. We need more female role models in management positions in ITES in order to break the gender equity paradox.

While the sample of this study is too small to warrant broad generalisations of the findings beyond the specific context of Mexico, the study still has significant implications in other contexts such as South Africa. There is emerging research on women in senior management positions in South African higher education (Ramohai 2019; Kayi 2013; Kele and Pietersen 2015; Moodly and Toni 2017), exploring the experiences of women in management positions. They also argue that few women are in senior management positions and face a different set of challenges as compared to their male counterparts. The status of women in senior management positions is actually a global challenge (Dines 1993). Thus, despite a plethora of gender equity policies and interventions, women throughout the world are underrepresented in management positions of key institutions. Our study therefore asks whether the gender equity policies are powerful enough to enable a significant restructuring of the gender imbalance in the higher education sector. We suggest that it might be an opportune moment to review most of the local and international policies in operation. Also, higher education institutions need to consider whether other social structures impede the progression of women into higher education management positions. The above questions attest to the persistent paradox of gender inequality and generate policy research and practical implications in other countries beyond Mexico.

\section{REFERENCES}

Angulo, L. and M. Galván. 2018. Avances en el cumplimiento de la esfera educación y capacitación de la mujer, a más de 20 años de la Plataforma de Acción de Beijing. Diálogos sobre educación Año 9(16): 1-12. http://www.scielo.org.mx/pdf/dsetaie/v9n16/2007-2171-dsetaie-9-16-00006.pdf (Accessed 18 September 2018).

Blickenstaff, J. C. 2005. Women and science careers: Leaky pipeline or gender filter. Gender and 
Education 17(4): 369-386. https://doi.org/10.1080/09542050500145072 (Accessed 10 September 2019).

CNDH. 2018. Estudio sobre la igualdad entre mujeres y hombres en materia de puestos y salarios en la administración pública federal (APF) 2017. Programa de asuntos de la mujer y de igualdad entre mujeres y hombres, México. https://www.cndh.org.mx/sites/all/doc/Informes/Especiales/ Estudioigualdad-20180206.pdf (Accessed 10 September 2019).

Connell, R. W. 1995. Masculinities. Berkeley: University of California Press.

Connell, R. W. 2000. The men and the boys. Berkeley: University of California Press.

Connell, R. W. 2005. Change among the gatekeepers: Men, masculinities, and gender equality in the global arena. Signs 30(3): 1801-1825.

Connell, R. W. 2009. Gender in the world perspective. Cambridge: Polity Press.

Diario Oficial de la Federación (DOF). 2014. Decreto que crea el Tecnológico Nacional de Mexico. México. http://www.dof.gob.mx/nota_to_doc.php?codnota=5353458 (Accessed 18 September 2018).

Dines, E .1993. Women in higher education management. Paris: Commonwealth Secretariat, UNESCO.

Ducklin, A. and J. Ozga. 2007. Gender and management in further education in Scotland: An agenda for research. Gender and Education 19(5): 627-646. https://doi.org/10.1080/09540250701535691 (Accessed 10 September 2019).

Economic Commission for Latin America and the Caribbean. 2013. El gasto etiquetado para las mujeres y la igualdad de género (GEMIG) en México: Un avance para garantizar la autonomía de las mujeres. Observatorio de igualdad de género de América Latina y el Caribe, México. https://oig.cepal.org/sites/default/files/el_gasto_etiquetado_para_las_mujeres_en_mexico_ esp.pdf (Accessed 10 September 2019).

Gaceta Parlamentaria, Número 4242-IV. 2015. http://gaceta.diputados.gob.mx/Black/Gaceta/ Anteriores/62/2015/mar/20150326-IV/Iniciativa-7.html (Accessed 10 September 2019).

González, A. 2015. El techo de cristal. Unpublished Masters' Thesis, Universidad de Oviedo, España. http://digibuo.uniovi.es/dspace/bitstream/10651/33742/3/TFM_GonzalezMartinez\%2C\%20Ana. pdf (Accessed 10 September 2019).

INEGI. 2017. Encuesta Nacional de Ocupación y Empleo. Tercer trimestre de 2017. Indicadores de género para población de 15 años y más, México. http://www.beta.inegi.org.mx/ proyectos/enchogares/regulares/enoe/ (Accessed 13 September 2018).

INEGI/INMUJERES. 2016. Mujeres y hombres en México, 2016. Instituto Nacional de las Mujeres, México. http://cedoc.inmujeres.gob.mx/documentos_download/MHM_2016.pdf (Accessed 10 September 2019).

Kayi, N. 2013. The progression of women to senior management positions at a South African University in the Western Cape. Unpublished Masters' Thesis, Cape Peninsula University of Technology, South Africa

Kele, T. and J. Pietersen. 2015. Women leaders in a South African higher education institution: narrations of their leadership operations. International Journal of Sustainable Development, 11-16.

Kelley, M. S and K. K. Bryan. 2018. Gendered perceptions of typical engineers across specialties for engineering majors. Gender and Education 30(1): 22-44. https://doi.org/10.1080/09540253. 2016.1262007 (Accessed 10 September 2019).

Lamas, M. 1996. La perspectiva de género. Consejo Nacional de Población, $3^{\mathrm{a}}$ edición, México. https://www.dgespe.sep.gob.mx/public/genero/PDF/LECTURAS/S_01_13_La\%20perspectiva\% 20de\%20g\%C3\%A9nero.pdf (Accessed 10 September 2019).

Lorber, J. 2010. Gender inequality: Feminist theories and politics. Oxford: Oxford University Press.

Lynch, I. and T. Nowosenetz. 2009. An exploratory study of students' constructions of gender in science, engineering and technology. Gender and Education 21(5): 567-581. https://doi.org/ 10.1080/09540250802555424 (Accessed 10 September 2019). 
Moodly, A. and N. M. Toni. 2017. Accessing higher education leadership: Towards a framework for women's professional development. South African Journal of Higher Education 31(3): 138-153.

Morojele, P. 2011. What does it mean to be a boy? Implications for boys and girls schooling experiences in Lesotho rural schools. Gender and Education 23(1): 1-17.

OECD. 2017a. Building an inclusive Mexico. Policies and good governance for gender equality. Paris: OECD Publishing. https://read.oecd-ilibrary.org/social-issues-migration-health/building-aninclusive-mexico_9789264265493-en (Accessed 10 September 2019).

OECD. 2017b. La lucha por la igualdad de género. Una batalla cuesta arriba. Paris: OECD. https://www.oecd.org/Mexico/Gender2017-MEX-es.pdf (Accessed 10 September 2019).

Ordorika. I. 2015. Equidad de Género en la Educación Superior. Revista de Educación Superior 44(174), abril/junio 2015. https://www.ses.unam.mx/integrantes/uploadfile/iordorika/Ordorika2015 EquidadDeGeneroEnLaEducSup.pdf (Accessed 10 September 2019).

Plan Nacional de Desarrollo 2013-2018. https://www.dof.gob.mx/nota_detalle_popup. php?codigo= 5299465 (Accessed 10 September 2019).

Programa para la cohesión social en América Latina. 2017. Guía para educación superior. La ética profesional y tu compromiso ciudadano. sii. http://www.sii.cl/destacados/sii_educa/contenidos/ docentes/jovenes/27-OP-201405295056.pdf (Accessed 10 September 2019).

Programa Regional de Desarrollo del Centro 2014-2018. http:/www.senado.gob.mx/ comisiones/ desarrollo_regional/docs/ProgRegDesarr_Centro2014_2018.pdf(Accessed 10 September 2019).

Programa Sectorial de Educación. 2013-2018. Instituciones de educación superior. https://www.ses.sep. gob.mx/instituciones.html. (Accessed 30 August 2018).

Ramohai, J. 2019. Women in senior management positions at South African universities: Their movement in, out and across universities. Gender in Management: An International Journal 34(3): 217-232.

Sampieri, R., C. Collado and P. Lucio. 2014. Metodologia de la investación. Editorial. New York: McGraw-Hill.

Subirats, M. 1998. La educación de las mujeres: De la marginalidad a la coeducación. Propuestas para una metodología de cambio educativo. Santiago de Chile, Chile: Serie mujer y desarrollo, CEPAL. https://repositorio.cepal.org/bitstream/handle/11362/5864/S9800068_es.pdf (Accessed 18 September 2018).

Subsecretaria de Educación Superior. 2018. https://educacionsuperior.sep.gob.mx/ (Accessed 11 September 2018).

TECNM. 2018a. Directorio telefónico de los IT's descentralizados. Tecnológico Nacional de México. $\mathrm{http}: / /$ sitio.tecnm.mx/reportes/directorio_descentralizados.php?str=6492d38d732122c58b44e3fd c3e9e9f3 (Accessed 10 September 2019).

TECNM. 2018b. Institutos Tecnológicos. Tecnológico Nacional de México. http://www.tecnm.mx/ informacion/institutos-tecnologicos-de-mexico (Accessed 10 September 2019).

TECNM. 2018c. Política de equidad de género. Tecnológico Nacional de México. http://www.tecnm. $\mathrm{mx} /$ informacion/politica-de-equidad-de-genero (Accessed 10 September 2019).

UNDP. 2017. La democracia paritaria en México: Avances y desafíos. Centro Regional del Programa de las Naciones Unidas para el Desarrollo. http://www.mx.undp.org/content/mexico/es/home/ library/democratic_governance/la-democracia-paritaria-en-mexico--avances-y-desafios.html (Accessed 10 September 2018).

UNESCO. 2018. Informe de seguimiento de la educación en el mundo 2018. Equipo del informe de seguimiento de la educación en el mundo. http://unesdoc.unesco.org/images/0026/ 002619/261945s.pdf (Accessed 10 September, 2018).

UN-Women. 2015. Los derechos políticos de las mujeres y cómo defenderlos. Cuaderno de trabajo. Entidad de las Naciones Unidas para la igualdad de Género y el Empoderamiento de las Mujeres, México. http://www2.unwomen.org/-/media/field\%20office\%20mexico/documentos/publica 
ciones $/ 2015 / 01 /$ derechos $\% 20$ poli $\%$ C3\%ACticos\%20de $\% 201$ as\%20mujeres.pdf?la=es\&vs=4038 (Accessed 10 September 2019).

Vega, L., G. Borunda, A. Bernal, G. Carmona, M. Cisneros, and F. Córdova. 2012. Modelo educativo para el siglo XXI. Formación y Desarrollo de Competencias Profesionales. Dirección General de Educación Superior Tecnológica. México. http://www.tecnm.mx/modeloeducativo/ modeloeducativo.pdf (Accessed 10 September 2018).

Volman, M., E. Van Eck and G. Tev Dam. 1995. Girls in science and technology: The development of a discourse. Gender and Education 7(3): 283-292. 